\title{
The activities of some metabolic enzymes in the intestines of germ-free and conventional chicks
}

\author{
BY MAUREEN F. PALMER*aND B. A. ROLLS $\dagger$ \\ National Institute for Research in Dairying, Shinfield, Reading, Berkshire RG2 9AT
}

(Received 8 March 1983 - Accepted 4 July 1983)

\begin{abstract}
1. The metabolic enzymes alkaline phosphatase (EC 3 .1.3.1), acid phosphatase (EC 3.1.3.2) and isocitrate dehydrogenase (EC 1.1.1.42) were measured in mucosal homogenates and these enzymes, together with glucose-6-phosphatase (EC 3 . 1.3.9), were measured in homogenates of isolated enterocytes from germ-free (GF) and conventional (CV) chicks which were either fed continuously until they were killed or were subjected to a $16 \mathrm{~h}$ fast before killing.

2. The intestine of the GF chicks was generally lighter than that of the CV controls. The activity of alkaline phosphatase was greater in the mucosal homogenates of the CV chicks compared with the GF birds, but the concentrations of acid phosphatase and isocitric dehydrogenase were not different in the two groups. In the isolated enterocytes the concentration of all enzymes expressed per mg DNA, except alkaline phosphatase, was higher in the GF chicks. Expressed per mg protein there was no significant difference in enzyme activity in the two groups.

3. Fasting caused a reduction in intestinal weight and total mucosal protein in both groups but the reduction was greater in the GF chicks compared with the CV controls. In the GF chicks, fasting caused a significant fall in acid phosphatase and isocitric dehydrogenase activities of the mucosal homogenate, whereas in the CV chicks only acid phosphatase fell to a significant extent. In the isolated enterocytes feeding caused a marked fall in protein per mg DNA in the CV chicks; fasting tended to reduce enzyme concentrations in the GF chicks but to have less effect in the CV group except for alkaline phosphatase where there was a marked rise in activity.

4. It is suggested that the difference in enzyme activities in the mucosal homogenates and isolated enterocytes might result from $(a)$ the presence of a much greater lamina propria in the CV compared with the GF chicks and (b) the greater mitotic activity in the fed CV chicks yielding a much larger number of smaller immature cells.
\end{abstract}

Growth rates in germ-free (GF) chicks have been shown to be approximately $10-15 \%$ faster than in conventional (CV) controls (Coates et al. 1963) and the characteristics of the small intestinal mucosa differ in the presence and absence of the microflora (Coates \& Fuller, 1977). In particular, the rate of turnover of the mucosal epithelial cells is more rapid in the CV intestine (Rolls et al. 1978). Thus the GF enterocytes are more mature than their CV counterparts and might perhaps develop a higher enzyme content which could be expected to lead to more efficient digestion or absorption or both. Enzymes were chosen for study which represented different activities within the enterocytes. Alkaline phosphatase (EC 3 .1.3.1) is located within brush borders where it may be concerned with the active uptake of nutrients, particularly lipids (Inglis et al. 1967), or with the hydrolysis of a wide range of phosphorylated compounds which cannot readily pass through cell membranes (Miller \& Crane, 1961). Glucose-6-phosphatase (EC 3.1.3.9) is located within the endoplasmic reticulum and although its function within the small intestine remains obscure, it has been implicated in insulin-insensitive glucose transport (Lygre \& Nordlie, 1968). There is some conflict as to whether oxidation of citrate in the respiratory chain proceeds through the NADP-linked enzyme (isocitrate dehydrogenase (NADP $\left.{ }^{+}\right) ; E C$ 1.1.1.42) or through the NAD-dependent enzyme (isocitrate dehydrogenase $\left(\mathrm{NAD}^{+}\right) ; E C$ 1.1.1.41). Smith \& Plaut (1979) have discussed the relative importance of the two enzymes in a recent review. It is possible that the NADP-linked enzyme functions in conditions of high energy demand or

* Present address: Department of Physiology, Queen Elizabeth College, University of London, Campden Hill Road, London W8 7AH.

$\dagger$ For reprints. 
in biosynthetic or control processes (Garland, 1968). Acid phosphatase (EC 3.1.3.2) is found in the lysosomes where it provides the energy for organelle destruction. Although GF chicks are heavier than CV birds the intestine is much lighter so calculation of specific enzyme activity based on protein or DNA content of the homogenate which includes the lamina propria may give erroneous estimates of enzyme activity of the enterocytes.

We performed two experiments: the first to measure enzyme activity in mucosal homogenates to give a measure of the total capacity of the gut, and the second using homogenates prepared from isolated enterocytes to give specific activities of the enzymes related to both protein content and DNA. Fasting reduces mitotic activity and causes marked depression of some enzymes, therefore measurements were made following a $16 \mathrm{~h}$ fast and after continuous feeding.

\section{MATERIALS AND METHODS}

Chicks. Rhode Island Red $\times$ Light Sussex chicks were used. Eggs from a specified pathogen-free flock maintained at the Institute were incubated for $18 \mathrm{~d}$ in a commercial incubator and then decontaminated with peracetic acid (Harrison, 1969). Those destined for the production of germ-free chicks were transferred to Gustafsson stainless-steel isolators to hatch, while the rest were returned to the incubator and the chicks subsequently hatched were reared as conventional controls. After hatching, the germ-free chicks were divided into groups of four and housed in stainless-steel cages with mesh floors inside the isolators, while the conventional controls were housed in similar cages in a room where environmental conditions could be matched to those in the isolators. Males and females were distributed evenly among the groups. Sterility checks on the chicks were made at weekly intervals (Fuller, 1968). Chicks aged 21-28 d were taken at the same time of day either following continuous feeding or after a $16 \mathrm{~h}$ fast.

Diets. The chicks were fed a practical mash (SCM), the composition of which was $(\mathrm{g} / \mathrm{kg})$ : maize meal 350 , wheat meal 300 , wheat middlings 85 , white fish meal 100 , dried skim milk 75 , dried grass meal 30 , dried brewers yeast 30 , limestone flour 15 , sodium chloride 4.697 , potassium iodide $3 \mathrm{mg}$, hydrated manganese sulphate 0.3 maize oil 10 . Cholecalciferol was dissolved in the maize oil to provide $16 \mu \mathrm{g} / \mathrm{kg}$ diet. A500 Rovimix (Roche Products, Welwyn Garden City, Herts) was added to give $2 \mathrm{mg}$ retinol $/ \mathrm{kg}$. The diet was packed in plastic bags which were evacuated and sterilized by $5 \mathrm{Mrad}$ gamma-radiation.

Chemicals. Laboratory chemicals were of Analar grade. Glucose-6-phosphoric acid, dipotassium salt and Folin-Ciocalteu reagent were supplied by British Drug Houses Ltd, Poole, Dorset. Other enzymes, enzyme substrates and chemicals were supplied by Sigma (London) Chemical Co., Poole, Dorset.

\section{Expt 1. Preparation of mucosal homogenates}

The chicks were anaesthetized with diethyl ether, the gut exposed and the small intestine from the gizzard to the ileocaecal junction washed out with a minimum quantity of ice-cold saline $(9 \mathrm{~g}$ sodium chloride/1). The whole intestine was then excised, weighed, cooled in ice and the chick killed. The intestine was opened lengthways, the mucosa removed by gentle scraping and then disrupted in ice-cold $0.1 \mathrm{M}-\mathrm{NaCl}$ with ultrasonic vibration (Dawe Instruments, London). The extract was prepared by stirring the homogenate for $60 \mathrm{~min}$ in an ice-bath and straining through cheesecloth. The total volume was made to $50 \mathrm{ml}$ with $0.1 \mathrm{M}-\mathrm{NaCl}$. A $20 \mathrm{ml}$ portion was mixed with an equal volume of $\mathrm{n}$-butanol and stirred for a further $60 \mathrm{~min}$ over ice. Both the saline and the saline-butanol extracts were centrifuged at $4500 \mathrm{~g}$ at $0-5^{\circ}$ to remove the debris and the saline-butanol extract was dialysed against distilled water at $0-4^{\circ}$ for $24 \mathrm{~h}$. Both extracts were stored at $-20^{\circ}$ until analysed. 


\section{Expt 2. Preparation of isolated cells}

The gut was exposed, washed through and removed as described previously. It was then cut into segments approximately $50 \mathrm{~mm}$ long. The segments were opened lengthways and incubated in saline containing serum albumin and hyaluronidase $(E C 3.2 .1$.35) for $30 \mathrm{~min}$ at $37^{\circ}$ with very gentle shaking (Kimmich, 1970). Gentle agitation then caused the cells to separate from the villus cores. The cells were then washed three times with fresh saline to remove the hyaluronidase and centrifuged at $100 \mathrm{~g}$ for $1 \mathrm{~min}$. The final cell pellet was suspended in $0.1 \mathrm{M}-\mathrm{NaCl}$ and extracts prepared as described previously. Samples of the cells and the villus cores were examined histologically and the cells were seen to be enterocytes with intact brush borders while the villus cores had lost approximately $90 \%$ of their cells.

Analytical methods. The protein content of the saline homogenate was measured by the method of Lowry et al. (1951) using Folin-Ciocalteu reagent and DNA was measured by the Schmidt-Tannhauser procedure as described by Fleck \& Munro (1962) using Burton's modification of the diphenylamine method (Burton, 1956). Isocitric dehydrogenase activity was measured by a method adapted from that of Ochoa (1948). Portions of the homogenate were added to a 'mixed' substrate of isocitric acid, NADP, $0.25 \mathrm{M}$-glycylglycine buffer at $\mathrm{pH} 7.4$ and manganese chloride to activate the enzyme and the change in optical density at $340 \mathrm{~m} \mu$ was then monitored over a period of $70 \mathrm{~s}$. Estimation of glucose-6-phosphatase was based on the method of Swanson (1955) but the maleic acid buffer was replaced by an EDTA buffer at $\mathrm{pH} 6.5$. The homogenate and buffered substrate were incubated at $37^{\circ}$ for $30 \mathrm{~min}$ and the phosphate released was measured by the method of Allen (1940), which is a slight modification of the method of Fiske \& SubbaRow (1925). Acid and alkaline phosphatases were measured by the method of Brandenberger \& Hanson (1953) using Tris-buffered $0.325 \mathrm{~mm}-o$-carboxyphenyl phosphate as a substrate. The saline-butanol extract was used for alkaline phosphatase assay and the saline extract for all other enzyme assays.

Statistical treatment. In these experiments there are two main factors, viz environment (presence or absence of a normal microflora) and fasting (presence or absence of food) and an interaction between environment and fasting. In all cases except that of isocitrate dehydrogenase, the untransformed data were analysed using analysis of variance on values from individual birds. For isocitrate dehydrogenase activity of the mucosal homogenates, there was evidence of skewness and variance heterogeneity in the data. The results were transformed into logarithms which removed the skewness but the variance heterogeneity remained, so the differences between the means of the transformed data were compared by $t$ tests. In the isolated enterocyte data there was little skewness but considerable variance heterogeneity and so $t$ tests were carried out on the untransformed data. In the text 'significant' means significant at the 0.05 level of testing.

\section{RESULTS}

Gut weight and mucosal protein. Although the GF chicks were 1.4 times as heavy as their CV counterparts the intestine was generally lighter, making up 0.030 of the body-weight compared with 0.042 in the CV birds. On fasting the gut weight was significantly decreased, the decrease being much more severe in the GF compared with the CV chicks and the interaction being significant in Expt 1 (Table 1) but not in Expt 2(Table 2). Mucosal protein content (Table 1) followed a similar pattern, although the greater fall on fasting in the GF compared with the $\mathrm{CV}$ chicks did not reach statistical significance. Protein expressed as $\mathrm{mg}$ per mg DNA (Table 2) was generally higher in the GF group and feeding caused a marked fall in the CV birds. 


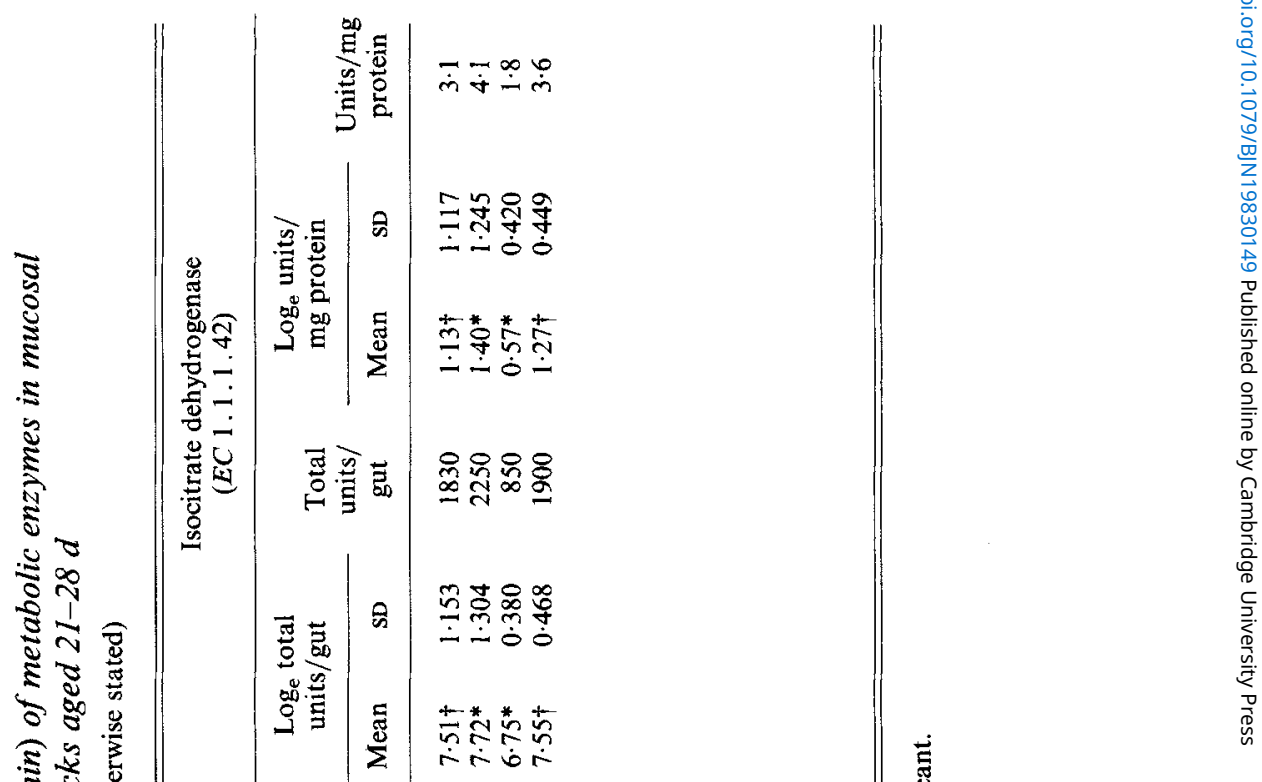

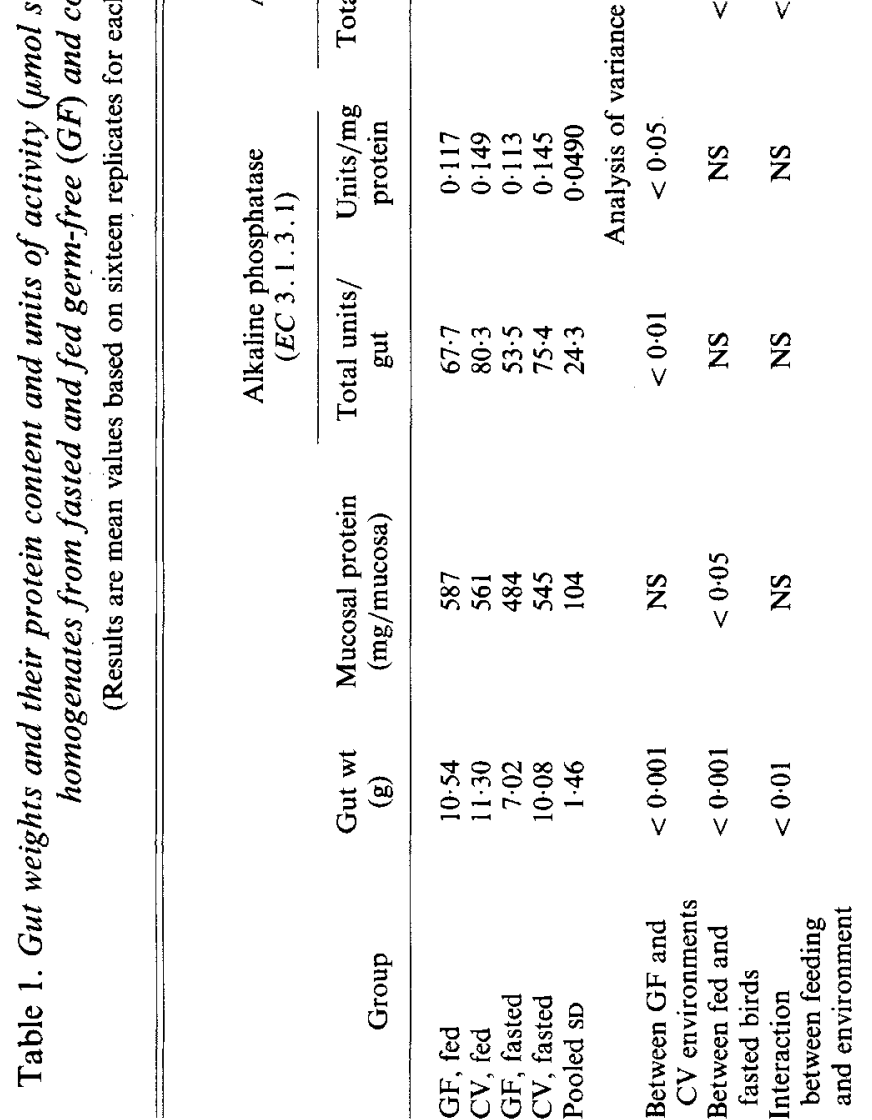


(5)

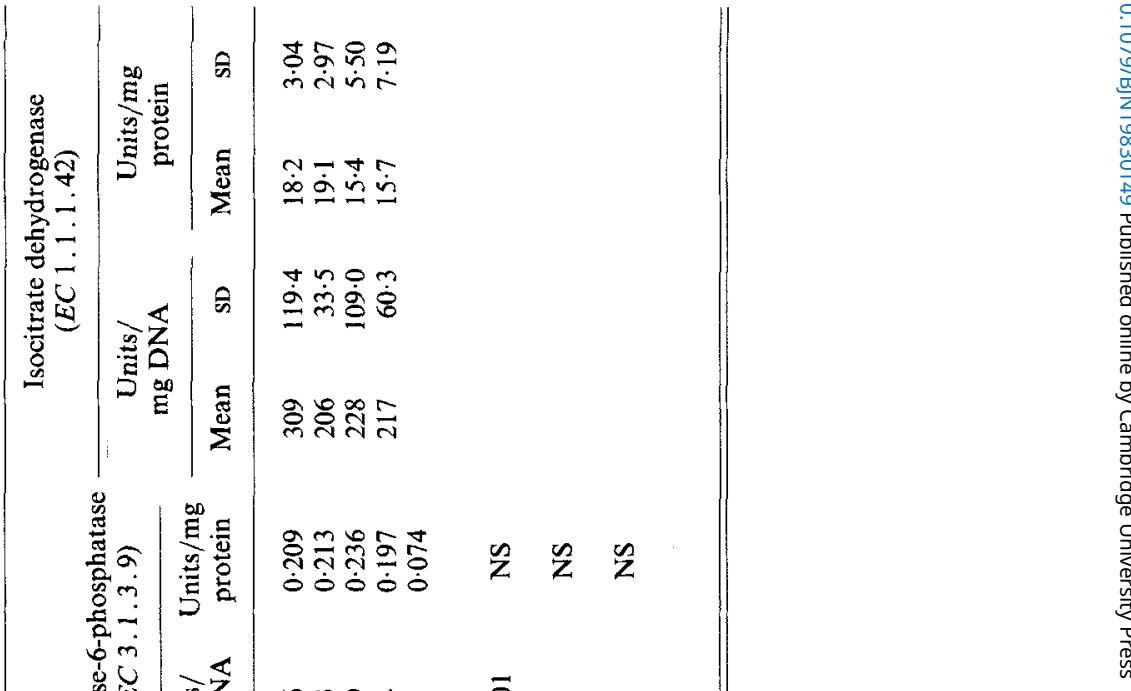

$\therefore$ is

总包

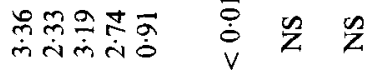

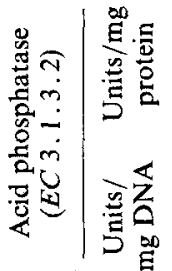

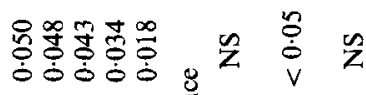

ठิ宀

.

है

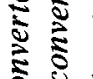

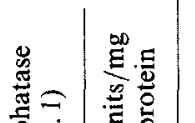

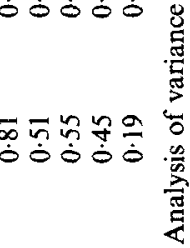

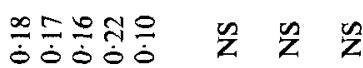

0

可

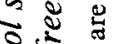

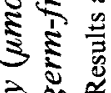

$\lambda \infty$

离

空

0

:

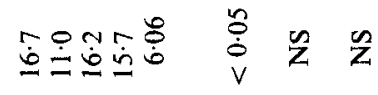

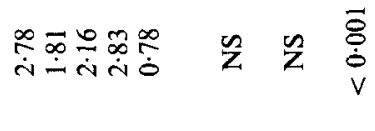

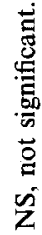
产台

离交

뎡

은

范

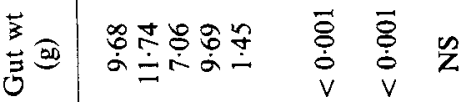

$\frac{2 \pi}{20}$

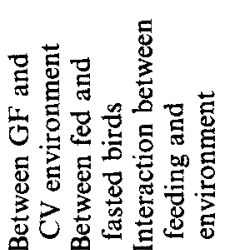


Mucosal homogenates. In general both total and specific activites of enzymes were higher in the CV chicks compared with their GF counterparts, as shown in Table 1 . The effect of environment was not significant in fed chicks whereas in the fasted birds only the effect on the specific activity of alkaline phosphatase failed to reach significance, although the over-all effect of environment on this enzyme was significant. Fasting tended to reduce enzyme activity; in the case of acid phosphatase there was a reduction of 50 and $30 \%$ in $\mathrm{GF}$ and $\mathrm{CV}$ chicks respectively. Isocitrate dehydrogenase activity was also significantly reduced by fasting in the GF chicks but the effect on the CV chicks was small.

Isolated enterocytes. Expressed as activity per mg DNA, enzyme activity tended to be lower in the CV compared with the GF chicks and significantly so in the fed chicks (Table 2) whereas, in the fasted chicks, the enzyme activities were not significantly different with the exception of alkaline phosphatase activity which was significantly higher in the CV chicks.

The effects of fasting were inconsistent. Acid phosphatase activity was reduced significantly in the GF but not in the CV chicks. Isocitrate dehydrogenase activity was also reduced though not significantly in the GF chicks. Glucose-6-phosphatase activity was little affected by fasting while alkaline phosphatase activity was reduced in the GF but increased in the $\mathrm{CV}$ chicks, both effects being significant. When expressed per $\mathrm{mg}$ protein most of these effects disappeared, although the over-all effect of fasting on acid phosphatase and isocitrate dehydrogenase was significant.

\section{DISCUSSION}

The common practice of expressing enzyme activity with reference to the weight of the mucosa or mucosal protein is not appropriate in comparison of GF and CV animals because of the difference in characteristics of the gut wall (Siddons \& Coates, 1971; Whitt \& Savage, 1980). The GF chick has a much thinner gut wall than its CV counterpart due to reduction of the lamina propria (Gordon \& Bruckner-Kardoss, 1961). The technique of mucosal scraping gives rise to a homogenate which includes both the enterocytes and the lamina propria but, since in the GF chick the lamina propria is reduced, the proportion of enterocytes will be relatively larger than in the CV homogenates. For this reason we considered a comparison of total enzyme activities in the homogenates of the mucosa of the whole small intestine to be more valid and we also measured enzyme activities in samples of isolated enterocytes.

Following continuous feeding, the intestinal weight of the CV chicks was considerably greater than that of the GF chick in both experiments. Fasting had a much more drastic effect on intestinal weight in the GF chicks than in the CV controls. In Expt 1 protein content was also measured and fasting reduced the gut weight by approximately $30 \%$ in the GF chicks compared with only $14 \%$ in the $\mathrm{CV}$ chicks and the total mucosal protein was reduced by $18 \%$ in the GF group compared with only $3 \%$ in the CV controls.

In the mucosal homogenate from the fed chicks, alkaline phosphatase activity was higher in the CV birds while activities of acid phosphatase and isocitrate dehydrogenase were similar in the two groups whether expressed as total units per gut or per mg protein. In the GF chicks fasting caused a significant fall in acid phosphatase and isocitric dehydrogenase activities of the mucosal homogenates but in the CV chicks only acid phosphatase fell by a significant amount.

Conversely, in Expt 2 with isolated enterocytes expressed per $\mathrm{mg}$ protein, alkaline phosphatase was not significantly affected by environment or fasting whereas acid phosphatase and isocitrate dehydrogenase, though not affected by environment, were reduced by fasting. When calculated per mg DNA the activities in the fed GF chicks were consistently higher than those in their CV counterparts. Fasting caused a fall in activity 
in the GF chicks but the effect in the CV birds was small except for alkaline phosphatase which was increased. Glucose-6-phosphatase was not examined in Expt 1 but in Expt 2 it followed a pattern similar to that of alkaline phosphatase.

If it is assumed that each cell has the same amount of DNA, then protein expressed per mg DNA in the isolated enterocytes (Table 2) gives an indication of cell size. In the fasted birds there was no difference in protein expressed per mg DNA and therefore in cell size in the two environments; however, in the fed chicks the protein per mg DNA was significantly less in the CV chicks indicating smaller cells. Previous work has shown that mitotic activity, cell migration rate and cell turnover is greater in the presence of the microflora (Rolls et al. 1978) and the present work suggests that feeding stimulates mitosis to a greater extent in the CV compared with the GF chicks. The greater mitotic activity in the CV state would result in a larger number of less mature cells so it might be expected that the enzyme concentration in the cell of the fed CV birds would be lower than in the GF group. This is borne out by the fact that enzyme activities expressed per mg DNA were consistently higher in the fed GF chicks compared with fed CV birds.

Comparing the enzyme activities in the isolated enterocytes and the whole mucosal homogenates, the results appear to be contradictory; the concentrations of enzymes in the cells of fed GF chicks were in general higher than those of their CV counterparts, whereas in the mucosal homogenates the concentrations of enzymes in the GF chicks tended to be similar or lower than those in the CV group. This difference probably reflects the contribution of the lamina propria where the cells no doubt contain these enzymes although they will play no role in the active uptake or utilization of nutrients. The difference in enzyme concentration expressed per mg DNA could perhaps be explained on the basis of a lower cell turnover rate in the GF group compared with the CV chicks; the greater enzyme concentration reflecting a greater cell maturity. The higher concentrations of enzymes in the more mature cells of the fed GF chicks might permit a more efficient transport and utilization of nutrients which would be advantageous to the bird, particularly since chicks feed continuously, and might help to explain the greater growth rate in the GF chicks. Nevertheless, the total activity in the mucosa of the fed CV chicks was as great or, in the case of alkaline phosphatase, greater than that of the fed GF chicks. The lamina propria would presumably be relatively unaffected by the presence of food in the gut and therefore its contribution to enzyme activity of the mucosal homogenate preparation would be a constant factor. The more severe effects of fasting on the GF chicks imply that in conditions of deprivation the presence of the microflora might be beneficial.

The authors wish to thank Dr Marie Coates for valuable help and encouragement during this work, Dr D. Hewitt for advice on statistical treatment, Dr D. Jayne-Williams for checking the sterility of the germ-free isolators, Mr A. Turvey for histological examination of the isolated cell preparations and Miss S. C. Woodley and Miss M. Tyler for technical assistance.

\section{REFERENCES}

Allen, R. J. L. (1940). Biochemical Journal 34, 858-865.

Brandenberger, H. \& Hanson, R. (1953). Helvetica Chimica Acta 36, 900-906.

Burton, K. (1956). Biochemical Journal 62, 315-323.

Coates, M. E. \& Fuller, R. (1977). In Microbial Ecology of the Gut, pp. 312-342. [R. T. J. Edwards and T. Bauchop, editors]. London and New York: Academic Press.

Coates, M. E., Fuller, R., Harrison, G. F. Lev, M. \& Suffolk, S. F. (1963): British Journal of Nutrition 17, $141-150$.

Fiske, C. H. \& SubbaRow, Y. (1925). Journal of Biological Chemistry 66, 375-400.

Fleck, A. \& Munro, H. N. (1962). Biochimica et Biophysica Acta 55, 571-583.

Fuller, R. (1968). In The Germ-free Animal in Research, pp. 37-45 [M. E. Coates, editor]. London and New York: Academic Press. 
Garland, P. B. (1968). In The Metabolic Roles of Citrate, pp. 41-60 [T. W. Goodwin, editor]. London: Academic Press.

Gordon, H. A. \& Bruckner-Kardoss, E. (1958). Antibiotics Annual 1012-1019.

Gordon, H. A. \& Bruckner-Kardoss, E. (1961). Acta Anatomica 44, 210-225.

Harrison, G. G. (1969). Laboratory Animals 3, 51-59.

Inglis, N. J., Krant, M. J. \& Fishman, W. H. (1967). Proceedings of the Society for Experimental Biology and Medicine 124, 699-702.

Kimmich, G. A. (1970). Biochemistry, Easton 9, 3659-3677.

Lowry, O. H., Rosebrough, N. J., Farr, A. L. \& Randall, R. J. (1951). Journal of Biological Chemistry 193, $265-275$.

Lygre, D. G. \& Nordlie, R. C. (1968). Biochemistry, Easton, 7, 3219-3226.

Miller, D. \& Crane, R. K. (1961). Biochimica et Biophysica Acta 52, 293-298.

Ochoa, S. (1948). Journal of Biological Chemistry 174, 133-157.

Rolls, B. A., Turvey, A. \& Coates, M. E. (1978). British Journal of Nutrition 39, 91-98.

Siddons, R. C. \& Coates, M. E. (1971). British Journal of Nutrition 27, 101-112.

Smith, C. M. \& Plaut, G. W. E. (1979). European Journal of Biochemistry 97, 283-295.

Swanson, M. A. (1955). In Methods in Enzymology, vol. 2, pp. 541-543 [S. P. Colwich and N. O. Kaplan, editors]. London and New York: Academic Press.

Whitt, D. D. \& Savage, D. C. (1980). Infection and Immunity 29, 144-151. 